Brigham Young University Law School BYU Law Digital Commons

Faculty Scholarship

5-31-1999

\title{
Team Production in Venture Capital Investing
}

D. Gordon Smith

Follow this and additional works at: https://digitalcommons.law.byu.edu/faculty_scholarship

Part of the Business Law, Public Responsibility, and Ethics Commons, Entrepreneurial and Small Business Operations Commons, and the Law Commons

\section{Recommended Citation}

D. Gordon Smith, Team Production in Venture Capital Investing, 24 J. CORP. L., 949 (1999).

This Conference is brought to you for free and open access by BYU Law Digital Commons. It has been accepted for inclusion in Faculty Scholarship by an authorized administrator of BYU Law Digital Commons. For more information, please contact hunterlawlibrary@byu.edu. 


\title{
Team Production in Venture Capital Investing
}

\author{
D. Gordon Smith*
}

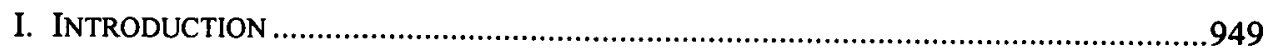

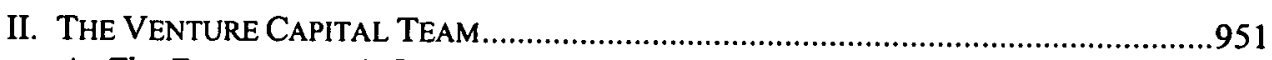

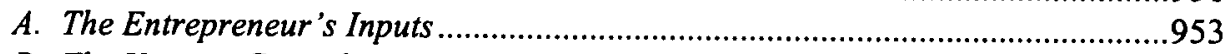

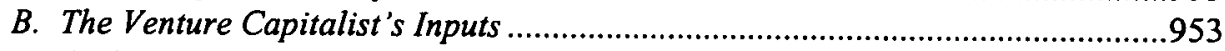

1. Serving as a Sounding Board to the Entrepreneur Team ...............................954

2. Obtaining Alternate Sources of Financing .................................................956

3. Recruiting Management Personnel .......................................................957

4. Interfacing with Investor Group ...........................................................958

5. Formulating Business Strategy.............................................................958

III. The Problem of Moral hazard IN Venture Capital Teams ...........................960

IV. Solutions to the Team Production Problem: The EConomic Models .........962

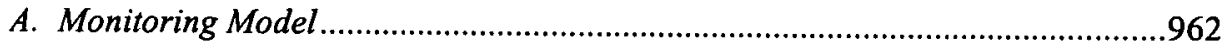

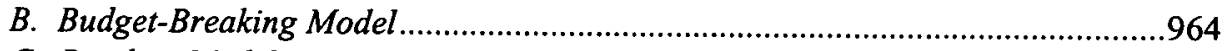

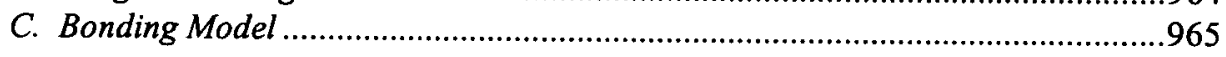

V. Solutions to the Team Production Problem: Venture Capital

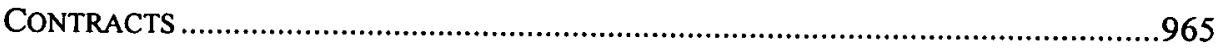

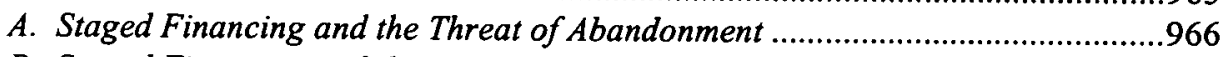

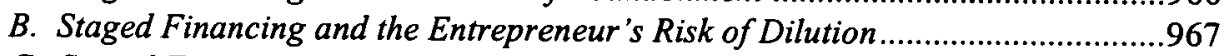

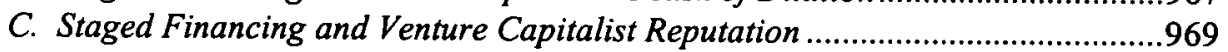

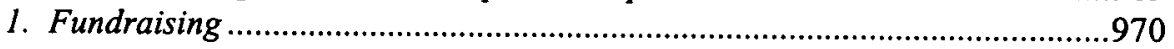

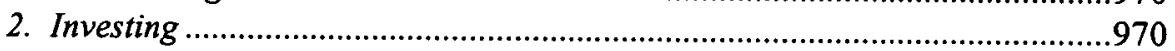

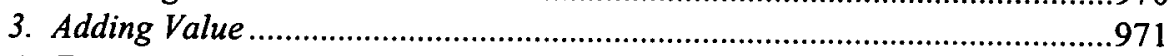

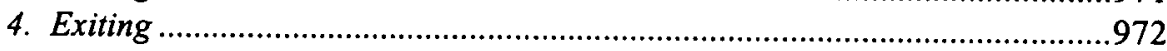

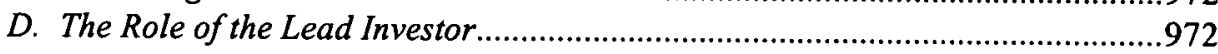

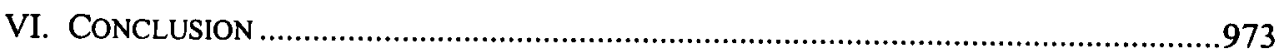

\section{INTRODUCTION}

The relationship between entrepreneur and venture capitalist has often been analyzed as an agency relationship, with the entrepreneur as the agent and the venture capitalist as the principal, ${ }^{1}$ but this characterization is too simple to capture the venture

* Associate Professor of Law, Northwestem School of Law of Lewis \& Clark College.

1. See, e.g., Paul A. Gompers, Optimal Investment, Monitoring, and the Staging of Venture Capital, $50 \mathrm{~J}$. FIN. 1461 (1995); William A. Sahlman, The Structure and Governance of Venture Capital Organizations, 27 J. FIN. ECON. 473 (1990). 
capital relationship. ${ }^{2}$ Although the relationship between entrepreneur and venture capitalist has elements of hierarchy, it is not a "pure agency relationship." ${ }^{3}$ In some ways, it is more like a partnership than a principal-agent relationship, with each contributing resources and expecting a share of the value generated by their joint effort. ${ }^{4}$ In the language of this symposium, entrepreneur and venture capitalist sometimes engage in "team production." 5

The task of analyzing venture capital contracts through the lens of team production is complicated by the fact that the relationship between entrepreneur and venture capitalist does not fit easily into existing economic models of team production. In short, their relationship is not "pure" team production, ${ }^{6}$ and relatively few attempts have been made to analyze relationships that combine elements of hierarchy and team. ${ }^{7}$

Rather than attempting to capture the complex interactions of entrepreneur and venture capitalist through an economic model, this Article will describe the team nature of the venture capital relationship using the rich set of facts provided by the book Startup: A Silicon Valley Adventure, ${ }^{8}$ which recounts how entrepreneur Jerry Kaplan and

2. See D. Gordon Smith, Venture Capital Contracting in the Information Age, 2 J. SMALL \& EMERGING BuS. L. 133, 138-40 (1998) (discussing the cooperative nature of the venture capital relationship); see also Sharon Gifford, Limited Attention and the Role of the Venture Capitalist, 12 J. BUS. VENTURING 459, 460 (1997).

3. This phrase comes from Michael C. Jensen \& William H. Meckling, Theory of the Firm: Managerial Behavior, Agency Costs and Ownership Structure, 3 J. FN. ECON. 305, 309 (1976). They contrast the "pure agency relationship" to a "cooperative relationship" (i.e., team production).

4. The language of "partnership" is frequently invoked in describing venture capital. See, e.g., WILLIAM D. Bygrave \& JefFry A. TIMMONS, Venture CAPITAL AT the Crossroads 207 (1992) ("We will argue that classic venture-capital investing is at its best when the suppliers and users of capital work in partnership.").

5. The study of "team production" originates with Armen A. Alchian and Harold Demsetz in their article Production, Information Costs, and Economic Organization, 62 AM. ECON. REV. 777 (1972). Alchian and Demsetz describe "team production" as having the following attributes: (1) several types of resources are used; (2) the product is not the sum of separate outputs of each cooperating resource; and (3) not all resources used in team production belong to one person. Id. at 777 . Bengt Holmstrom adopted a more expansive definition of "team" to mean "a group of individuals who are organized so that their productive inputs are related." Bengt Holmstrom, Moral Hazard in Teams, 13 BELL J. ECON. 324, 325 (1982). The relationship between entrepreneur and venture capitalist fits comfortably within either definition of team.

6. As noted in Part III, infra, the assumptions underlying most economic models of team production are quite confining and do not closely resemble the venture capital relationship discussed here.

7. See Roy Radner, Hierarchy: The Economics of Managing, 30 J. ECON. LIT. 1382, 1405 (1992) (observing the absence of "significant progress on more comprehensive theoretical models of the firm that combine these two submodels in a systematic way"). For an attempt at analyzing a "mixed" agency/team relationship, see Masahiko Aoki, The Contingent Governance of Teams: Analysis of Institutional Complementarity, 35 INT'L ECON. REV. 657 (1994).

8. See generally JERRY KAPLAN, STARTUP: A SiliCON VALley ADVENTURE (1994). Referring to Startup and another popular account of an entrepreneur raising venture capital, MICHAEL WOLFF, BURN RATE: HOW I SURVIVED THE GOLd RUSH YeARS ON THE INTERNET (1998), Professors Colin Mason and Richard Harrison recently noted,

In addition to their intrinsic interest, these accounts can provide a valuable insight into the entrepreneur's perspective of the fund-raising process, including negotiation and deal structure issues, which has attracted only limited attention by researchers, and might even represent a new quasi-primary data source. 
his venture capitalists at Kleiner Perkins Caufield \& Byers, the most prominent venture capital firm in Silicon Valley, formed and operated GO Corporation. ${ }^{9}$ Kaplan's account provides a highly textured picture of the ways in which entrepreneurs and venture capitalists build a company and the mechanisms they use to ensure that their relationship is productive.

The Article begins in Part II with a description of the Venture Capital Team, which is comprised of the "Entrepreneur" and the "Venture Capitalist." Both are referred to in the singular for purposes of simplification, even though the Entrepreneur is usually a team of individuals and the Venture Capitalist often might include several venture capital firms and perhaps more than one person per firm. Part III briefly describes the team production problem in terms of moral hazard (more specifically, "shirking"). Although adverse selection may also be problematic in team production, especially because it interacts with moral hazard in affecting the output of the team, ${ }^{10}$ the initial work on team production focused on the moral hazard problem, and that is where the primary challenges lie. ${ }^{11}$ With the nature of the problem firmly fixed, Part IV proceeds to review the approaches to resolving the team production problem in three economic models: the monitoring model; the budget breaking model; and the bonding model. As already noted, the existing economic models are inadequate, standing alone, to explain the structure of venture capital contracting, but they provide useful insights about how contractual mechanisms might address the team production problems in venture capital financing. Finally, Part V concludes by examining the role of staged financing in addressing the team production problem. The terms of venture capital contracts exhibit great variety, but staged financing is nearly universal in these transactions, and it seems to provide at least a partial solution to the moral hazard problem.

\section{The Venture Capital Team}

In most emerging companies, a team of entrepreneurs forms the core operational group, and that group may contain multiple overlapping teams and principal-agent relationships. The relationship between the team of entrepreneurs ("Entrepreneur") and the venture capitalists ("Venture Capitalist") typically is designed to deal with strategic issues that reside at a higher level of abstraction than most operational issues. The Entrepreneur and Venture Capitalist comprise the Venture Capital Team, and the goal of this section is to describe their respective inputs into the team production process, using the history of GO Corporation as described in Startup: A Silicon Valley Adventure. ${ }^{12}$

GO Corporation-a pioneer in the field of pen-based computing-received its initial funding from Kleiner Perkins Caufield \& Byers ("KP") after a single presentation by

Colin M. Mason \& Richard T. Harrison, Editorial. Venture Capital: rationale, aims and scope, 1 VENTURE CAP. 1, 13 (1999)

9. The use of case studies is no longer fashionable in conventional economics literature, but it is making a comeback among certain economists. See, e.g., John N. Drobek \& John V.C. Nye, Introduction to THE FRONTIERS OF THE NEW INSTITUTIONAL ECONOMICS Xv (John N. Drobek \& John V.C. Nye eds., 1997).

10. See generally R. Preston McAfee \& John McMillan, Optimal Contracts for Teams, 32 INT'L ECON. REV. 561 (1991) (including a trade-off between moral hazard and adverse selection in the model).

11. Alchian \& Demsetz, supra note 5, at 779-80 (focusing on shirking); Holmstrom, supra note 5, at 327 (same).

12. KAPLAN, supra note 8. 
Jerry Kaplan to the KP partners, with "No business plan, no 35-millimeter slides, no charts, no financial projections, no prototypes." 13 The initial investment of $\$ 1.5$ million came from KP, Mitchell Kapor (the founder of Lotus Development Corporation, who had inspired Kaplan's original insight into pen-based computing), and a few other individual investors. In exchange for the money, the investors received a thirty-three percent interest in the new company in the form of Series A Preferred Stock. ${ }^{14}$ Kaplan noted that his idea-and since GO Corporation had not even been formed, it was only the idea-had been valued at $\$ 3$ million. 15

In exchange for their money, the investors demanded and received significant rights of control over the new venture. For example, in addition to Kaplan, the four-person board of directors" included two KP partners-John Doerr and Vinod Khosla- and Mitchell Kapor. ${ }^{16}$ More importantly for purposes of this Article, both the investors and Kaplan knew that $\$ 1.5$ million would be far short of the amount of capital necessary to fully develop Kaplan's idea into a marketable product. Indeed, GO Corporation eventually raised $\$ 75$ million over six years before its ignominious death by acquisition. ${ }^{17}$ As discussed more fully in Part V, the Venture Capitalist exerts enormous control over portfolio companies by forcing them to raise capital repeatedly in a process called staged financing, the practice of investing only enough money to allow the Entrepreneur to progress to the next milestone in its business plan. The Venture Capitalist's power derives from the fact that the initial decision whether to proceed with the project belongs to the Venture Capitalist.

The defining attribute of team production is that the inputs of team members are "unobservable." That is, direct observation of a team member's performance is impossible, or prohibitively costly, or the inputs of the team member are indistinguishable-from the standpoint of one who is attempting to reward productivity-from the inputs of other team members. ${ }^{18}$ The unobservability of inputs makes compensation of team members based on those inputs impractical and inefficient. The goal, therefore, is to structure the compensation system based on team outputs, which are easily observable. The following sections briefly discuss both the Entrepreneur's and the Venture Capitalist's inputs to illustrate the problems of observation in the Venture Capital Team.

13. Id. at 23 .

14. Id. at 28 . Kaplan would retain $25 \%$ and two other senior officers (yet to be identified) would each receive $8.3 \%$. The remaining $25.4 \%$ was reserved for future employees. Id.

15. Id. at 29.

16. KAPLAN, supra note 8, at 28.

17. Id. at 1 . The $\$ 75$ million represents both equity and debt financing and earned GO Corporation the distinction (shared with Momenta Corporation) of "World's Biggest Failure" by Inc. magazine. Failure Hall of Fame, INC., May 1, 1998, at 78. ("II]n Silicon Valley ... the rules of failure are different; far from amounting to a demerit, a past bankruptcy is almost a credential.").

18. Cf. Alchian \& Demsetz, supra note 5, at 780 ("In team production, marginal products of cooperative team members are not so directly and separably (i.e., cheaply) observable."); McAfee \& McMillan, supra note 10, at 561 ("The synergy that is the reason for the team's existence may mean that an individual's contribution to the team's output is not distinguishable, so that it is impossible to pay him according to his own productivity."). 


\section{A. The Entrepreneur's Inputs}

The inputs of the Entrepreneur are many and varied and encompass every aspect of operating a company. Some inputs-such as the selection of key employees ${ }^{19}$ or performance at public announcements ${ }^{20}$-are easily observable, and the Venture Capitalist could cheaply monitor such inputs for evidence of shirking. Other inputs are less observable because direct observation is impossible (e.g., Entrepreneur's willingness to seize opportunities ${ }^{21}$ ) or very costly (e.g., Entrepreneur's efforts to motivate employees ${ }^{22}$ ) or because the inputs are indistinguishable from the inputs of other team members (e.g., Entrepreneur and Venture Capitalist both court additional investors ${ }^{23}$ ). These types of activities are widely understood to be part of the Entrepreneur's responsibilities and do not merit extended discussion here.

\section{B. The Venture Capitalist's Inputs}

Like the Entrepreneur, the Venture Capitalist contributes some inputs to the company that are readily observable. The most obvious of these is capital. It is well known, however, that the Venture Capitalist contributes more than capital to its portfolio companies. The Venture Capitalist also contributes so-called "value-added services." In a recent survey, entrepreneurs were asked to rate the importance of twelve value-added services to their choice of a venture capitalist. ${ }^{24}$ The five services achieving the highest ratings were the following: (1) serving as a sounding board to entrepreneur team; (2) obtaining alternate sources of financing; (3) recruiting management personnel; (4) interfacing with investor group; and (5) formulating business strategy. ${ }^{25}$ These results closely track the results obtained in many other surveys of entrepreneurs ${ }^{26}$ and venture

19. See, e.g., KAPLAN, supra note 8, at 29-33 (describing Kaplan's efforts to recruit Robert Carr and Kevin Doren as vice-presidents in charge of software and hardware, respectively).

20. See, e.g., id. at 163-69 (introducing the "Penpoint" computer).

21. See, e.g., id. at 74-76 (hiring an employee from Yugoslavia on the basis of a journal article on handwriting recognition).

22. See, e.g., id. at 50 (adopting an Uncle Milton's Ant Farm as the company mascot).

23. See, e.g., id. at 78-81 (sealing the financing with Aneas Investors).

24. D. Gordon Smith, How Early Stage Entrepreneurs Evaluate Venture Capitalists (Apr. 10, 1999) (unpublished manuscript, on file with author at Northwestem School of Law of Lewis \& Clark College). The sample was comprised of early stage entrepreneurs that received venture funding during the last three quarters of 1997 and the first quarter of 1998. The twelve value-added services included in the survey were the following: (1) developing actual product or service; (2) formulating business strategy; (3) formulating, testing, or evaluating marketing plans; (4) interfacing with investor groups; (5) managing crisis problems; (6) monitoring the company's performance; (7) motivating personnel; (8) obtaining altemate sources of financing; (9) recruiting management personnel; (10) selecting vendors and equipment; (11) serving as a sounding board to entrepreneur team; and (12) soliciting customers or distributors.

25. Id.

26. See, e.g., Joseph Rosenstein et al., The CEO, Venture Capitalists, and the Board, 8 J. BUS. VENTURING 99, 105 (1993) (CEOs of venture-backed firms rated the following services of outside directors highest: serving as a sounding board to the management team, interfacing with investor group, monitoring financial performance, monitoring operating performance, recruitment and/or replacement of CEO); Sanford B. Ehrlich et al., After the Cash Arrives: A Comparative Study of Venture Capital and Private Investor Involvement in Entrepreneurial Firms, 9 J. BUS. VENTURING 67, 75 (1994) (entrepreneurs rated the following services highest: interfacing with investor group, obtaining alternative equity financing, monitoring financial 
capitalists, 27 thus suggesting a large degree of consensus regarding the relative importance of value-added services provided by venture capitalists.

The focus of team production analysis is whether the Venture Capitalist has the proper incentives to exert itself in providing value-added services. Using principal-agent analysis (casting the Entrepreneur as principal and the Venture Capitalist as agent), resolution of that issue would depend largely on whether the Venture Capitalist's activities are easily observable to the Entrepreneur or some other principal. As illustrated below, some aspects of the Venture Capitalist's services appear to be easily observable, and compensation based on productivity would be practical. In other instances, however, the services are not easily observable. For purposes of this Article, it is enough to show that a significant level of services provided by the Venture Capitalist is not easily observable by the Entrepreneur or another principal. This is the essence of the team production problem. ${ }^{28}$ Each of the following Parts briefly illustrates how KP provided these services to GO Corporation. ${ }^{29}$

\section{Serving as a Sounding Board to the Entrepreneur Team}

Serving as a sounding board to the entrepreneur team is part of a set of activities through which the Venture Capitalist assists the Entrepreneur in developing a competitive strategy. ${ }^{30}$ One suspects that the ability of the Venture Capitalist to perform this activity may be closely related to the Venture Capitalist's prior operating experience, which is an important factor considered by many entrepreneurs in selecting a venture capitalist. ${ }^{31}$

performance, serving as a sounding board to entrepreneur team, monitoring operating performance, and formulating business strategy).

27. See, e.g., Ian C. MacMillan et al., Venture Capitalists' Involvement in Their Investments: Extent and Performance, 4 J. BUS. VENTURING 27, 32 (1989) (venture capitalists rated the following services highest: serving as a sounding board to the entrepreneur team, obtaining altemate sources of equity financing, interfacing with the investor group, monitoring financial performance, and obtaining alternate sources of debt financing); see also Harry J. Sapienza \& Jeffry A. Timmons, The Role of Venture Capitalists in New Ventures: What Determines Their Importance?, in ACADEMY OF MANAGEMENT BEST PAPERS PROCEEDINGS 74, 75 (1989) (venture capitalists and entrepreneurs both rated the following roles highest: sounding board and business consultant).

28. Even where services are easily observable, compensation based on productivity may not be feasible, not because of difficulty in measuring the value of the services (after all, many management consultants provide fee-based services that are similar to the services provided by the Venture Capitalist), but rather because most startup ventures have a negative cash flow. This problem is unrelated to the team production problem.

29. Of course, venture capitalists provide other value-added services, albeit on a less systematic basis. In the case of GO Corporation, for example, John Doerr arranged a meeting between Jerry Kaplan and the director of the Research Board, an exclusive group of the top chief information officers in the United States and potential customers for GO Corporation. KAPLAN, supra note 8, at 84-85.

30. Harry J. Sapienza, When Do Venture Capitalists Add Value?, 7 J. BUS. VenturING 9, 13 (1992).

31. See Smith, supra note 24 (reporting that in a rating by entrepreneurs of the importance of venture capitalist attributes, prior operating experience earned a mean rating of 6.15 on a scale from 0 to 10 , which was higher than every value-added service on the same scale, except serving as a sounding board to the entrepreneur team and obtaining alternate sources of financing.); see also Rosenstein et al., supra note 26, at 110 (describing responses by entrepreneurs to open-ended questions indicating their disappointment with the level of prior operating experience of their venture capitalists). 
John Doerr was trained as an electrical engineer and had extensive operating experience prior to becoming a venture capitalist. ${ }^{32}$ Moreover, he has worked as a venture capitalist with some of the most visible high-technology companies in the United States, including Compaq, Intuit, Netscape, Sun Microsystems, and Amazon. ${ }^{33}$ When he tutors young entrepreneurs, therefore, he brings a wealth of experience to the table. Some of the most memorable meetings between Kaplan and Doerr resemble therapy more than business counseling. For example, after receiving a proposal from IBM during COMDEX (the large computer industry conference) to purchase GO Corporation, Kaplan sought out Doerr for advice and found him in a corridor of the Las Vegas Hilton. Finding no place to sit, "John dropped to the floor" and the following conversation ensued:

John looked exasperated. "Jerry, do you want to sell out?" he asked.

"No, not particularly. I don't think I have the patience to work for IBM."

"Right, then don't give in. ... That's not what we're in this for." John's voice grew louder. "We've got work to do, and we can do it without them if we have to." He was working himself into a frenzy. . . . "Just tell [IBM] it's not for sale." 34

In this brief exchange, Doerr was providing Kaplan with useful support, encouraging Kaplan to pursue his preferred course of action. It is worth remembering that Doerr was not a disinterested party, but someone who had a financial stake in Kaplan's decision, perhaps even ultimate control over the outcome. By reducing Kaplan's uncertainty, Doerr permitted the company to pursue its business strategy with renewed focus.

About three months after the COMDEX meeting, Kaplan had another close encounter with IBM and again turned to his venture capitalists. GO Corporation was depending on IBM to invest $\$ 5$ million, but the proposed terms for the investment "were virtually guaranteed to put GO out of business," 35 according to Kaplan. Kaplan called Khosla, who advised him, "Come home. ... They're not serious. There's no point in continuing the discussions." 36 Perhaps not completely satisfied with Khosla's response, which would have dramatically altered the course of the company, Kaplan also called Doerr, who took a different tack: "You're going to have to do something to turn them around. One way or another, you have to make this deal. GO's survival depends on it."37 Contrary to the stereotype of venture capitalists as control freaks, the ultimate decision was left to Kaplan and he succeeded in closing the deal on more favorable terms. ${ }^{38}$

Later in GO Corporation's development, Kaplan approached Doerr for advice on relieving the pressures of his position:

32. See KCBP Team Partners: John Doerr (visited May 10, 1999) <http://www.kpcb.com/team/ johndoert.html>.

33. Id.

34. KAPLAN, supra note 8 , at 130.

35. Id. at 142 .

36. Id. at 143 .

37. Id.

38. Id. at 145. 
"John, I'm burning myself up. I'm working the equivalent of two, fulltime jobs. What should I do?"

"That's easy, let's split your job in half." The logic of this simple observation was compelling. "Engage a headhunter and we'll look for a chief operating officer. And get out and do something this weekend." I took both suggestions. ${ }^{39}$

What appears at first as largely a personal matter might signal an important transition in the development of the company. Although still burning through capital at an astounding rate, GO Corporation had reached a point in its development when additional leadership was required. Doerr was helping Kaplan to understand that transition.

All of this seems simple enough, but acting as a sounding board is the service that entrepreneurs in survey after survey rate as one of the most important services provided by venture capitalists. ${ }^{40}$ Even though the activity of the Venture Capitalist is easily observable to the Entrepreneur, valuing this input may be difficult. The nature of the activity is such that the Venture Capitalist and the Entrepreneur are working cooperatively, exchanging ideas and feeding off each other's insights. From a team production standpoint, therefore, the value of the service is not easily separable from the activity of the Entrepreneur and apportioning compensation according to the Venture Capitalist's contribution may be difficult.

\section{Obtaining Alternate Sources of Financing}

High-growth businesses like GO Corporation are perpetually seeking new sources of financing. Prior to an initial public offering, after which the company can access public capital markets, the Entrepreneur relies heavily on the network of contacts provided by the Venture Capitalist. Financing may be in the form of debt or equity securities. In either event, the value of the Venture Capitalist's work in obtaining additional financing is not easily distinguishable from the value added by the Entrepreneur.

John Doerr was most visible at times when GO Corporation needed additional financing (which, admittedly, was quite regularly during its short life). In one early round of financing, Kaplan describes Doerr reeling off a list of possible investors, starting with other venture capital firms and moving through institutional investors, potential corporate partners, investment banks, and "angel" investors. ${ }^{41}$ In addition to providing names, the KP partners advised Kaplan regarding valuation and negotiation strategy ${ }^{42}$ and assisted potential investors with their due diligence investigations. ${ }^{43}$ On the third round of financing, which is described more fully below, Doerr ultimately negotiated the price with the outside investors. ${ }^{44}$

39. KAPLAN, supra note 8 , at 157.

40. See sources cited in notes 26-27.

41. KAPLAN, supra note 8, at 68-69. Angel investors, who comprise the market for "informal venture capital," have been described as "self-made, high net worth individuals who invest in unquoted companies in which they have no family connection." Mason \& Harrison, supra note 8, at 9.

42. KAPLAN, supra note 8 , at $62-64,74$.

43. Id. at 72 .

44. Id. at $79-80$. 
Certainly, some of the Venture Capitalist's efforts to obtain additional financing are observable by the Entrepreneur, but even if the Entrepreneur can observe the Venture Capitalist's behavior it may be difficult to measure the Venture Capitalist's productivity. If both recruit a potential investor who ultimately invests in the company, how does one distinguish their relative contributions to that effort? Moreover, shortcomings in this area might be evidenced by what is left undone. As noted by Bernard Black and Ronald Gilson, "A venture capitalist can choose not to make or return telephone calls." 45 Such shirking might be nearly impossible for the Entrepreneur to uncover. From a team production standpoint, therefore, the value of the Venture Capitalist's service in obtaining additional capital is not easily observable, and rewarding the Venture Capitalist based on its contribution would be difficult.

\section{Recruiting Management Personnel}

When the Venture Capitalist spends a significant amount of time recruiting new managers, the company is likely in trouble. This could stem from the fact that troubled companies are the ones most likely in need of new management, but it is also possible that the Venture Capitalist's involvement causes performance problems. ${ }^{46}$ Regardless of the causation, it is clear that many Entrepreneurs seek the Venture Capitalist's assistance in locating potential managers, ${ }^{47}$ and the Venture Capitalist views this as an important function. ${ }^{48}$

KP had two occasions to recruit new managers for GO Corporation. The first was a director to replace Mitchell Kapor, who resigned from the board for personal reasons. With one telephone call to Doerr, Kaplan located a new prospect in David Liddle, cofounder and then CEO of Metaphor Computer Systems, Inc. ${ }^{49}$ Liddle joined the board of GO Corporation shortly thereafter.

The second occasion arose several months after Kaplan confessed his need for a reduced workload to Doerr. GO Corporation had not located a chief operating officer, so Doerr and Khosla approached Kaplan about the possibility of hiring Bill Campbell--then

45. Bernard S. Black \& Ronald J. Gilson, Venture Capital and the Structure of Capital Markets: Banks Versus Stock Markets, 47 J. FIN. ECON. 243, 254 (1998).

46. See MacMillan et al., supra note 27, at 39 (suggesting various explanations for the connection between poor performance and time spent searching for venture management).

47. See, e.g., Ehrlich et al., supra note 26, at 80 (finding that "entrepreneurs seek financial and staffing expertise from their primary investors"). Also, the results of Smith's survey of entrepreneurs, see supra note 24 , suggest that many entrepreneurs select venture capitalists because of their extensive network of industry contacts. In that survey, entrepreneurs rated industry specialization sixth among the 29 factors presented. One of the main benefits of industry specialization, of course, is that the venture capitalists develop a network of contacts who might serve in management positions. Based on the results of the survey, this benefit appears to outweigh several other potential benefits of industry specialization. For example, expertise in an industry might enable the venture capitalist to assist in the following services: developing the actual product or service of the company; formulating, testing, or evaluating marketing plans; selecting vendors or equipment; or soliciting customers or distributors. But each of these services received relatively low ratings from the entrepreneurs.

48. Vinod Khosla recently commented on the importance of recruiting management personnel: "It's probably the single most difficult thing we do. In fact, we really consider ourselves glorified headhunters in many ways. Hard work, lots of networking, and persistence in pursuing good candidates is the key to success in our business." Voices Events With . . Vinod Khosla, WALL ST. J. INTERACTIVE EDITION (visited Feb. 23, 1999) $<$ http://interactive.wsj.com/archive/retrieve.cgi?id=SB919726331626979500.djm\&template=voices.tmpl>.

49. KAPLAN, supra note 8 , at 95 . 
CEO of Claris, a subsidiary of Apple Computer-as the new CEO for GO Corporation. ${ }^{50}$ Although Kaplan was forced to give up his position as CEO ("I wasn't in this for the job title"), 51 he assumed the position of chairman of the board. ${ }^{52}$

Like so much of what the Venture Capitalist does, the work of Doerr and Khosla in recruiting new managers on behalf of GO Corporation could have been left undone without Kaplan being any the wiser. In this case, the problem is not that their contribution was indistinguishable from Kaplan's, but rather that it would be practically impossible for Kaplan or any other principal to monitor their efforts to develop the network of contacts that enables them to provide this service.

\section{Interfacing with Investor Group}

The Venture Capitalist plays an important role as intermediary between the Entrepreneur and other investors. That role includes providing information to other investors about whether to continue investing in the company. ${ }^{53}$ Kaplan mentions one instance in which Doerr was asked to speak to the other investors. During a late round of financing, Doerr undertook to speak to the other investors about investing their pro rata share. ${ }^{54}$ Marshaling ongoing support for a portfolio company helps to ensure a steady base of investors and can make an enormous difference to the Entrepreneur. Like the Venture Capitalist's efforts in recruiting management personnel, the Entrepreneur cannot practically observe the interaction with other outside investors.

\section{Formulating Business Strategy}

In the same survey in which entrepreneurs identified the most important value-added services, they were also asked to rate the importance of various attributes to their selection of a venture capitalist. Of the seven attributes listed, entrepreneurs rated industry specialization highest. ${ }^{55}$ Certainly, knowledge of a particular industry would assist the Venture Capitalist in providing strategic advice to the Entrepreneur, and entrepreneurs appear to value that advice highly.

KP was intimately involved in every stage of GO Corporation's development, but a particularly crucial moment, when the company decided to distinguish itself from Microsoft by changing from an Intel processor to another, is worthy of more detailed consideration. The story begins at a meeting of the entire board of directors, who were gathered to discuss the decision. Doerr was leading the discussion of possible corporate

50. Id. at 159 .

51. Id.

52. Id.

53. See, e.g., Anat R. Admati \& Paul Pfleiderer, Robust Financial Contracting and the Role of Venture Capitalists, 49 J. FIN. 371, 387 (1994) (describing the "certification" role of the Venture Capitalist).

54. KAPLAN, supra note 8 , at 150 .

55. The other choices included the following: amount of capital available to the venture capitalist; investment-stage specialization of the venture capitalist; number of years the venture capitalist has been in the venture capital industry; physical location of the venture capitalist; prior operational experience of the venture capitalist; and whether venture capitalist is a Small Business Investment Company (SBIC). Smith, supra note 24. 
partners, 56 and Khosla was offering strategic analysis. GO Corporation viewed the change in processors as an opportunity to attract new corporate partners. Khosla asserted that there were only two viable options: the ARM chip, which had been developed by a British technology company, and the Hobbit chip, which had been developed by AT\&T. AT\&T originally developed the Hobbit for Apple Computer's pen computing project (called Newton), but Apple unexpectedly canceled the project and switched to the ARM. ${ }^{57}$ The ARM chip had also been adopted by an English company called Active Book for its pen computer, and everyone at GO Corporation liked the thought of a transatlantic partnership between GO and Active Book. As luck would have it, Active Book had recently approached KP for financing, and another KP partner (Bernie Lacroute) had close relationships with AT\&T. Khosla suggested approaching AT\&T about converting to the ARM chip. What follows is a textbook example of value-added services:

John rubbed the heel of his hand with a handkerchief. "Bob Kavner, a group executive at AT\&T, has a keen interest in communication devices. He's worked closely with Bernie Lacroute, who has just joined Kleiner Perkins from Sun. Let's ask Bernie if he would be interested in starting such a venture with Kavner and AT\&T based on the ARM chip."

It turned out that KP had been in discussions with Active Book for some time, just as we had been quietly sounding out AT\&T on developing some sort of partnership. Nonetheless, Bill [Campbell], Randy [Komisar, GO's chief financial officer and vice president of business operations], and I were stunned into silence. It seemed implausible that AT\&T would ditch tens of millions of investment dollars at the urging of one of the KP partners. Yet John seemed quite serious, and Vinod was nodding his head in approval.

John was eager to charge ahead. "I'll get the ball rolling." He bolted down the hall to find a phone, presumably to call Lacroute, with Vinod close behind.

Bill looked bemused by this new turn. "I guess the meeting's over. Let's let them give it a try, then we'll get this thing back on track."

Randy shot me a skeptical look. I shrugged and said, "Look, they've made more outlandish suggestions than this-and been right."

Soon Lacroute was on a plane to AT\&T headquarters in New Jersey, to put this proposition to Bob Kavner. It was no surprise when he returned emptyhanded. John Doerr called to give us the news.

"Kavner wouldn't go for it," he said over the speaker phone in Bill's office. Randy mouthed the words "Of course," then adjusted his chair so he could balance his head against the wall. "So I called Active Book," John said,

56. Kaplan wrote that Doerr "had a habit of popping up at board meetings and writing lists of potential global partners on the whiteboard. On this occasion, his ideas for alliances were so broad that they resembled a tutorial on World War II." KAPLAN, supra note 8, at 201.

57. Id. at 201-04. 
"and asked if they would switch to the Hobbit instead, if we agree to fund them."

Randy grabbed a comer of the desk as though someone had tried to tip his chair over. This was equally unlikely. Active Book was just about to release its own ARM-based product. Not to mention that the CEO, Hermann Hauser, was part of the team that had developed the ARM in the first place.

"And?" Bill said, as straight as he could. I was clutching my stomach, trying not to laugh out loud.

John paused, then said, "And they agreed. So Bernie's now working with Kavner, who's interested in funding the whole GO hardware engineering team, combining it with Active Book, and starting a global GO spinoff-if my partner Bernie will nun it."

Randy snapped his chair upright with a bang. I was so shocked that I stood straight up. None of us could speak.

“Hello?" John said. "Are you guys still there?"

Bill moved his jaw up and down several times, trying to get his mouth into gear. "Uh, yes, we're here, John." He couldn't think of anything else to say.

John continued, making the matter sound entirely routine. "We need to get a proposal in front of them ASAP. Randy, can you work something up?"

"We can do that," Randy said, regaining his composure. "You'll have it first thing Monday."

Bill hung up the phone. Randy shook his head and said, "Gee, Toto, I don't think we're in Kansas anymore. Bill, if I ever question these KP guys again, kick me." 58

Like being a sounding board, the Venture Capitalist's role in developing corporate strategy is observed by the Entrepreneur, but the Venture Capitalist's contribution to the ultimate success of the company is difficult to quantify and compensate directly. ${ }^{59}$

\section{The Problem of Moral hazard in Venture Capital Teams}

The Entrepreneur and the Venture Capitalist work together to build a successful company, and they share the fruits of their joint production. The essence of the team

58. Id. at 203-04.

59. Of course, management consultants may provide similar services that are fee-based, but by combining consulting services with equity investment, the Venture Capitalist functions as a "reputational intermediary" in a manner that would be difficult for a management consultant to emulate. See Black \& Gilson, supra note 45 , at 254-55 ("Combining financial and nonfinancial contributions both enhances the credibility of the information that the venture capitalist provides to third parties and bonds the venture capitalist's promise to the portfolio company to provide nonfinancial assistance."). 
production problem is that team members have an incentive to shirk. ${ }^{60}$ The term "shirking" is not intended to be pejorative, despite the judgmental sound of "moral hazard."61 As stated by Holmstrom, this is "the problem of inducing agents to supply proper amounts of productive inputs when their actions cannot be observed and contracted for directly."62

The incentive to shirk derives from the inability to monitor team members perfectly and compensate them based on productivity. Alchian and Demsetz provide the classic description of this incentive problem:

Both leisure and higher income enter a person's utility function. Hence, each person should adjust his work and realized reward so as to equate the marginal rate of substitution between leisure and production of real output to his marginal rate of substitution in consumption. That is, he would adjust his rate of work to bring his demand prices of leisure and output to equality with their true costs. However, with detection, policing, monitoring, measuring or metering costs, each person will be induced to take more leisure, because the effect of relaxing on his realized (reward) rate of substitution between output and leisure will be less than the effect on the true rate of substitution. His realized cost of leisure will fall more than the true cost of leisure, so he "buys" more leisure (i.e., more nonpecuniary reward).

If the team member's relaxation cannot be detected perfectly at zero cost, part of its effects will be borne by others in the team, thus making his realized cost of relaxation less than the true total cost to the team. The difficulty of detecting such actions permits the private costs of his actions to be less than their full costs. Since each person responds to his private realizable rate of substitution (in production) rather than the true total (i.e., social) rate, and so long as there are costs for other people to detect his shift toward relaxation, it will not pay (them) to force him to readjust completely by making him realize the true cost. Only enough efforts will be made to equate the marginal gains of detection activity with the marginal costs of detection, and that implies a lower rate of productive effort and more shirking than in a costless monitoring, or measuring, world. ${ }^{63}$

These abstract propositions can easily be recast in the context of a venture capital investment. For example, one might assume that Kaplan and Doerr each adjusts his efforts on behalf of GO Corporation to obtain his preferred balance between leisure and

60. See Alchian \& Demsetz, supra note 5, at 780.

61. For an interesting exploration of moral hazard from another perspective, see Tom Baker, On the Genealogy of Moral Hazard, 75 TEX. L. REV. 237, 240 (1996) ("By 'proving' that helping people has harmful consequences, the economics of moral hazard justify the abandonment of legal rules and social policies that try to help the less fortunate; and, by providing a 'scientific' basis for the abandonment of legal rules and social policies, the economics of moral hazard legitimate that abandonment as the result of a search for truth, not an exercise of power.").

62. Holmstrom, supra note 5 , at 324.

63. Alchian \& Demsetz, supra note 5, at 780. 
effort. ${ }^{64}$ If all of their efforts were readily observable and if compensation were perfectly calibrated to productivity, both would have the right incentives to exert themselves. There would be no shirking because each would bear the full costs of his own decision to shirk. But some of their efforts are not observable and compensation cannot be perfectly calibrated to individual productivity. As a result, any costs of shirking would be borne by both Kaplan and Doerr in the form of a less valuable company (i.e., lower output). When the costs of shirking are shared, both have an incentive to shirk.

The temptation to shirk on any particular venture may be more pronounced for the Venture Capitalist than for the Entrepreneur. Sharon Gifford has observed that a Venture Capitalist has "limited attention"- that is, a constrained ability to "allocat[e] time to directing, advising, and monitoring the venture." 65 Because the Venture Capitalist is involved in many ventures simultaneously, there is a "discrepancy between the amount of attention that maximizes the Venture Capitalist's expected profit from the venture and that which maximizes the entrepreneur's expected profit."66 Viewed in the context of GO Corporation, Doerr may not have made a tradeoff between leisure and effort so much as a tradeoff between effort for GO Corporation and effort for another portfolio company. The fact that the Venture Capitalist has limited attention should prompt the Entrepreneur to seek incentives for the Venture Capitalist that are unique to the Entrepreneur's company.

\section{Solutions to the Team Production Problem: The Economic Models}

The team production problem in venture capital contracting is now quite transparent: given the impossibility of rewarding the Entrepreneur and the Venture Capitalist based on their inputs to the company, how does one divide the output of the Venture Capital Team in such a way that provides proper incentives to both the Entrepreneur and the Venture Capitalist? Recognizing the inherent limits on any incentive structure based on inputs, several economists have proposed possible solutions that would achieve efficient results in a team production context. Unfortunately, the economic models do not bear a strong resemblance to venture capital contracts. ${ }^{67}$ Nevertheless, many of the models contain useful insights into the operation of venture capital contracts. The following sections describe the major economic models and discuss their possible application to venture capital contracting.

\section{A. Monitoring Model}

Alchian and Demsetz famously argued that shirking within a firm could be reduced to an efficient level by a principal who specializes in monitoring. ${ }^{68}$ Assigning the

64. Alchian and Demsetz use "leisure" to represent all nonpecuniary income, and they assume that increased effort is directly related to increased income. Id.

65. Gifford, supra note 2, at 460.

66. Id. at 461 .

67. Kenneth Arrow suggested that economic models are more complex than actual contracts, though less complex than actual relations. He notes that simple contracts are used to specify complex relationships because the cost of contracting is high: "There is a cost to the very statement of the contract, a cost to understanding it and its implications, and a cost to verifying which terms apply in a given situation." Kenneth J. Arrow, Agency and the Market, in HANDBOOK OF MATHEMATICAL ECONOMICS 1183, 1193 (Kenneth J. Arrow \& M.D. Intriligator eds., 3d ed. 1986).

68. Alchian \& Demsetz, supra note 5, at 781-82. 
principal title to the residual earnings of the team ${ }^{69}$ would encourage the principal to engage in the right amount of monitoring activity. ${ }^{70}$

Alchian and Demsetz assume that "Clues to each input's productivity can be secured by observing behavior of individual inputs."71 This assumption severely compromises their analysis, however. As noted by Masahiko Aoki, "it is vital for their argument to presume the principal's perfect ability to observe the individual actions of team members, once properly motivated. The perfect observability assumption, however, renders the concept of teams almost meaningless."72 Even if Aoki's criticism is a bit overstated, it should be clear from the discussion above that observing the behavior of the Entrepreneur and the Venture Capitalist would not be feasible for a third-party principal in many instances. Moreover, as conceded by Alchian and Demsetz, even if a principal were able to observe the actions of the Entrepreneur and the Venture Capitalist, such observation would not reliably measure their productivity. More specifically, Alchian and Demsetz note that "watching a man's activities is not a good clue to what he is actually thinking or doing with his mind."73

Another problem with the monitoring model in the context of a Venture Capital Team is that both the Entrepreneur and the Venture Capitalist are residual owners. Alchian and Demsetz noted that "the cost of team production is increased if the residual claim is not held entirely by the central monitor." 74 An accommodation in the monitoring model is made for "profit-sharing firms," which are characterized by few members and high costs of managing inputs. ${ }^{75}$ Alchian and Demsetz argue that profit sharing-and the reciprocal monitoring that is permitted by the smaller teams-may be a useful substitute to centralized monitoring. ${ }^{76}$ To the extent that monitoring is effective at all (i.e., to the extent that the inputs are easily observable and rewards can be correlated with productivity), it certainly happens in the Venture Capital Team. But these aspects of the relationship are better viewed through the principal-agent lens (with the two parties owing reciprocal agency obligations), rather than as part of the team production problem.

Although monitoring does not provide a useful solution to the team production problem in venture capital contracting, Alchian and Demsetz make two useful contributions to the analysis. The first relates to the observability of inputs. Where teams are small, the costs of observation should be small in comparison to large teams. Alchian and Demsetz note, however, that observability depends not only on the number of inputs but on the nature of those inputs. In the Venture Capital Team, many of the inputs are simply not susceptible to observation, even if the team member's behavior is observable.

Alchian and Demsetz's second contribution to the analysis is the recognition that the team members would be required to assign to the principal the power to revise the

69. Alchian and Demsetz define residual earnings as all eamings remaining after the team members are paid for their inputs. Id. at 782 .

70. This is the amount at which the marginal costs of monitoring equal the marginal benefits of shirking reduction. Id.

71. Id. at 780 .

72. Aoki, supra note 7 , at 659 .

73. Alchian \& Demsetz, supra note 5, at 786.

74. Id.

75. Id.

76. Id. 
contract terms of the team members. ${ }^{77}$ This power-or another that serves the same function ${ }^{78}$ - must be part of any solution to the team production problem. If members of a team share the team's output among themselves according to fixed compensation rules, each team member will have an incentive to shirk. In the venture capital context, for example, most financings involve the issuance of preferred stock to the Venture Capitalist. If the company is successful, that preferred stock typically will be converted to common stock upon an initial public offering of the company's shares. Absent subsequent changes, therefore, the initial investment would fix compensation for the Entrepreneur and the Venture Capitalist at a proportionate share of the value created by their collaboration. Under such a structure, both would have an incentive to shirk, knowing that the other would incur part of the cost of shirking. Any solution to the team production problem in venture capital contracting, therefore, must allow for reallocation of rewards after the initial investment to penalize shirking.

\section{B. Budget-Breaking Model}

Bengt Holmstrom argued that the primary role of the principal is not monitoring, but "budget breaking."79 Under Holmstrom's model, team members receive their proportionate share of the team's output only if the team meets or exceeds a targeted level of output. If the team's actual output falls short of the targeted level, the team members receive nothing. Because such draconian penalties will not be self-imposed, ${ }^{80}$ Holmstrom suggests that the team will employ a principal whose sole function is to break the budget-that is, to impose penalties on the underperforming team. The principal is also entitled to retain any output in excess of the targeted level. ${ }^{81}$

The introduction of a principal creates a hierarchical relationship with members of the team and resolves the moral hazard problem inherent in team production. Nevertheless, this has been called an "unrealistically drastic way of solving the moralhazard problem." 82 More significantly, the presence of the principal creates a new moral hazard problem. As noted by Mukesh Eswaren and Ashok Kotwal, "Since the principal's payoff is discretely greater when the team output falls marginally short of the Pareto optimal level than when it does not, he actually prefers the agents to shirk."83 Moreover, Holmstrom's model suffers from the fact that it does not enforce the optimal outcome, but rather allows for many equilibrium solutions. ${ }^{84}$ Kenneth Arrow has noted that

77. Id. at 782 .

78. See the discussion of the bonding model, infra Part IV.C.

79. Holmstrom, supra note 5 , at 328 ("[T]he primary role of the principal is to administer incentive schemes that police agents in a credible way rather than to monitor agents as in Alchian and Demsetz' story.").

80. Eric Rasmusen argues that risk-averse agents could precommit to budget-balancing contracts in which punishments are determined by lottery rather than surrendering the entire output to a third party. The punishments might be imposed on one agent ("scapegoat" contracts) or on all agents except one ("massacre" contract). Eric Rasmusen, Moral Hazard in Risk Averse Teams, 18 RAND J. ECON. 428, 428-29 (1987).

81. In addition, Holmstrom notes that the principal may "not provide any (unobservable) productive inputs or else a free-rider problems remains." Holmstrom, supra note 5, at 328.

82. McAfee \& McMillan, supra note 10 , at 561 .

83. Mukesh Eswaren \& Ashok Kotwal, The Moral Hazard of Budget-Breaking, 15 RAND J. ECON. 578, 579 (1984).

84. See Irene Valsecchi, Why Capital Hires Labor in Team Production, $151 \mathrm{~J}$. INSTITUTIONAL \& THEORETICAL ECON. 467, 468 (1995). 
because Holmstrom's model contemplates a "collective punishment," 85 "If some individuals shirk a little, it pays the others to work somewhat harder to achieve the same output."86

Despite these difficulties, Holmstrom's model has some attributes that recommend it to the analysis of venture capital contracts. First, the notion of a principal whose primary relationship to the team is budget breaking seems an essential attribute of any solution to the team production problem, given the inherent failure of monitoring. As noted above, the authority of a principal to realign the claims of team members is crucial to the success of team production, and this authority presumes the power to break the budget. Second, the principal relies on the output of the team for guidance regarding rewards. This allows the principal to act without reference to inputs, which are (by definition) too costly or impossible to observe. As with budget-breaking authority, this is an essential attribute of any solution to the team production problem.

\section{Bonding Model}

Preston McAfee and John McMillan considered a simple bonding solution to the team production problem where moral hazard was the only concern. ${ }^{87}$ Under this model, the principal collects money from each of the agents prior to production. 88 Each agent would pay the principal an amount equal to the expected value of the team's total output, less the agent's production cost. ${ }^{89}$ Following production, the principal would distribute the total value of the team's output to each agent. ${ }^{90}$ In accordance with the analysis above, this solution to the moral hazard problem breaks the budget and has the salutary benefit of being based on team output, rather than on monitoring. The bonding model resembles Alchian and Demsetz's realignment of claims and Holmstrom's collective punishment, but represents a different path to the solution. Nevertheless, it may be subject to serious wealth constraints by the agents. ${ }^{91}$

\section{Solutions to the Team Production Problem: Venture Capital Contracts}

Jerry Kaplan described the "startup game" played by most companies that receive venture capital:

It begins with an aspiring entrepreneur who is willing to step right up and be tested. As in many other games, the player starts with an artificial currency-in this case, the stock of the new venture. The goal is simple: increase the value of the entrepreneur's shares, because when the game is over, these can be cashed in for real money. The trick is to swap some of the stock for three resources-

\footnotetext{
85. Arrow, supra note 67 , at 1191-92.

86. Id.

87. See generally McAfee \& McMillan, supra note 10, at 562.

88. Id.

89. Id.

90. Id.

91. Aoki, supra note 7, at 660 ; Holmstrom, supra note 5 , at 328.
} 
ideas, money, and people-then use these resources to increase the value of the remaining stock. ${ }^{92}$

Kaplan thus points to the core of the team production problem in the venture capital context: once the Entrepreneur has purchased the necessary resources from the Venture Capitalist with shares of stock, how can each ensure that the other will expend sufficient effort in pursuit of increased value? Left to their own devices, each has an incentive to shirk. The economic models discussed above teach that the solution to this problem must involve (1) a principal (2) with authority to break the budget by realigning the claims of team members through use of a penalty or a bonding arrangement (3) based only on observations of team output, not on monitoring of individual performance.

\section{A. Staged Financing and the Threat of Abandonment}

The team production problem is universal (or nearly so) in venture capital contracting, but venture capital contracts exhibit surprising variation. ${ }^{93}$ One aspect of the contracting process that appears pervasive, however, is staged financing of investments. As stated earlier, staged financing is the practice of investing only enough money to allow the Entrepreneur to progress to the next milestone in its business plan. Before the money runs out, the Entrepreneur must begin the process of raising the next round of financing. At each stage, the Venture Capitalist typically has a right of first refusal, allowing the Venture Capitalist to participate in the financing by purchasing the number of new shares sufficient to ensure that the Venture Capitalist retains a steady level of ownership in the company. ${ }^{94}$ Whether the Entrepreneur is successful depends largely on the progress made with the previous installment of funds. ${ }^{95}$

Viewed through a principal-agent lens, staged financing responds to information asymmetries between the Entrepreneur and the Venture Capitalist. ${ }^{96}$ The Entrepreneur is more knowledgeable than the Venture Capitalist about the progress and prospects of the company, but placing the decision regarding continued investment in the hands of the Entrepreneur would be unwise because the Entrepreneur receives private benefits from the continued operation of the company. ${ }^{97}$ The Entrepreneur, therefore, has an incentive to overinvest. ${ }^{98}$

The Venture Capitalist could monitor the firm and invest continuously, but monitoring is expensive. As noted by Paul Gompers:

92. KAPLAN, supra note 8 , at 21-22.

93. See Richard J. Testa, The Legal Process of Venture Capital Investment, in PRATT'S GUIDE TO Venture CAPITAL Sources 65, 65 (Yong Lim \& Ted Weissberg eds., 1994) ("Despite increasing standardization of the venture capital process, it remains, fundamentally, highly idiosyncratic, with each transaction reflecting the particular chemistry between entrepreneur and investor. Accordingly, there exists no such thing as the 'perfect model' of legal documentation in the investment transaction.").

94. William A. Sahlman, The Structure and Governance of Venture Capital Organizations, 27 J. FIN. ECON. 473, 505 (1990).

95. See id. at 506-08. Of course, a rational Venture Capitalist will analyze the net present value of the project, ignoring sunk costs. Nevertheless, the Entrepreneur's past performance will be the best evidence available to the Venture Capitalist of the future eamings prospects of the company. Id.

96. See Gompers, supra note 1 , at 1464.

97. Id.

98. Id. 
In practice, venture capitalists incur costs when they monitor and infuse capital. Monitoring costs include the opportunity cost of generating reports for both the venture capitalist and entrepreneur. If venture capitalists need to "kick the tires" of the plant, read reports, and take time away from other activities, these costs can be substantial. Contracting costs and the lost time and resources of the entrepreneur must be imputed as well. Each time capital is infused, contracts are written and negotiated, lawyers are paid, and other associated costs are incurred. ${ }^{99}$

Staged financing places the investment continuation decision in the hands of the Venture Capitalist, but limits the costs of monitoring to discrete time periods, with occasional contacts between financings. 100

Because the Venture Capitalist is not required to provide financing at any stage in the process, staged financing allows the Venture Capitalist to abandon ventures whose prospects are dim, thus resolving adverse selection problems. ${ }^{101}$ The possibility of abandonment also provides incentives that address the risk of entrepreneurial moral hazard. These incentives arise because of the threat of abandonment-a threat that is particularly potent because the refusal by the Venture Capitalist to continue investing will likely be viewed by other potential investors as a signal that the company is unworthy of capital. As a result, the Entrepreneur will have a strong incentive to avoid abandonment by the Venture Capitalist. Paul Gompers has noted the dual effects of the Venture Capitalist's ability to abandon an unprofitable venture, stating that "The role of staged capital infusion is analogous to that of debt in highly leveraged transactions, keeping the owner/manager on a 'tight leash' and reducing potential losses from bad decisions." 102

\section{B. Staged Financing and the Entrepreneur's Risk of Dilution}

The foregoing benefits of staged financing to the Venture Capitalist are well recognized, but the benefits of staged financing also extend to the team production problem of the Venture Capital Team. The starting point for this analysis is the recognition that staged financing also benefits the Entrepreneur. Kaplan offered his view of staged financing:

The entrepreneur doesn't raise all of the required money up front because that would mean selling too much of the stock. Usually, the initial investment is just enough to reach some identifiable milestone. This milestone is chosen to demonstrate to potential future investors that the company's prospects have improved, justifying a higher price for the stock, so that less of it has to be sold.

If the money runs out before the milestone is reached, the game is over. ${ }^{103}$

Kaplan's simple observation is crucial to understanding the role of staged financing in solving the team production problem. From the Entrepreneur's perspective, the prospect of abandonment is not the only danger in staged financing, and it may not even

99. Id. at 1464 .

100. Id. at 1464-65.

101. See Smith, supra note 2, at 138.

102. Gompers, supra note 1 , at 1462

103. KAPLAN, supra note 8, at 22. 
be the most important. Another danger is that subsequent rounds of financing may substantially dilute the Entrepreneur's interest in the company. Obviously, the Entrepreneur would rather have the risk of dilution inherent in staged financing than the certainty of dilution that would follow from lump sum financing. But it is precisely this risk that best addresses the Entrepreneur's incentives to shirk in the team production context.

The effects of this risk are best appreciated by comparing the incentives produced by the threat of abandonment with the incentives produced by the threat of dilution. The Entrepreneur can avoid abandonment by creating a company that passes the Venture Capitalist's investment hurdle. This is certainly not an easy task, but the incentives are limited (i.e., once the Entrepreneur is confident of clearing the hurdle, unobserved shirking goes unpunished). On the other hand, the Entrepreneur avoids dilution only by creating a successful company, and the incentives are unrestrained. The more successful the company, the less dilution occurs.

Kaplan's experience with GO Corporation powerfully illustrates the dilutive effect of staged financing on the Entrepreneur's interest. According to valuations provided in the book, the shareholdings after the first round of investments would be approximately as follows: ${ }^{104}$

$\begin{array}{lrl}\text { KP and other outside investors } & 3,750,000 & (33 \%) \\ \text { Jerry Kaplan } & 2,840,909 & (25 \%) \\ \text { Kevin Doren } & 943,182 & (8.3 \%) \\ \text { Robert Carr } & 943,182 & (8.3 \%) \\ \text { Other employees } & \underline{2,886,363} & (25.4 \%) \text { (reserved) } \\ \text { TOTAL } & \underline{11,363,636} & \end{array}$

The second round of financing came only three months after the first round and involved the same outside investors, who paid $\$ 500,000$ for an additional 833,333 shares. ${ }^{105}$ At that point, the outside investors owned $4,583,333$ shares, or $38 \%$ of the total shares outstanding or reserved for issuance to employees, and Kaplan's ownership share had already been reduced to $23.3 \%$. The company was valued at approximately $\$ 6$ million. ${ }^{106}$

GO's third round of financing was more difficult than the first two. Although the initial outside investors were enthusiastic about the company's progress, valuation was extremely subjective. Mitchell Kaplan suggested that the company was worth at least double the previous valuation ( $\$ 12$ million), but John Doerr argued for a valuation of $\$ 20$

104. KAPLAN, supra note 8 , at 28 (stating that the outside investors, including KP and several individual investors, would receive $33 \%$ of the shares of the company in exchange for $\$ 1.5$ million; that Kaplan would receive $25 \%$ of the shares of the company; that two vice-presidents would each receive $8.3 \%$ of the shares of the company; and that the remainder (25.4\%) would be reserved for future employees); see also id. at 62 (stating that the initial financing was completed at a price of $\$ .40$ per share). The calculations assume, for the sake of simplicity, that the shares attributed to Kaplan, Doren, and Carr were owned outright by each from the beginning. Although Kaplan does not mention a vesting schedule, often the Entrepreneur's shares are subject to delayed vesting. See, e.g., Sahlman, supra note 94, at 505.

105. KAPLAN, supra note 8 , at 62 .

106. Id. This was a rough calculation based on 10 million shares outstanding, suggesting that many of the employee shares had not yet been issued. 
million! ${ }^{107}$ By the time Kaplan actually began to speak with potential investors (other venture capital firms), the asking price reached $\$ 14$ million, ${ }^{108}$ and he eventually settled for a valuation of $\$ 8$ million. ${ }^{109}$ At that valuation, GO Corporation raised "over $\$ 6$ million." 110 The approximately 8 million new shares increased the ownership interest of the outside investors to at least $62.3 \%$ and reduced Kaplan's stake to approximately $14 \% .^{111}$

The fourth round of equity financing was led by State Farm, ${ }^{112}$ a potential customer, which agreed to a valuation of nearly $\$ 75$ million. ${ }^{113}$ Intel also invested in this round, and GO Corporation raised $\$ 15.31$ million, ${ }^{114}$ issuing $6,124,000$ new shares. ${ }^{115}$ After this round, the outside investors owned approximately $71.3 \%$ of GO Corporation, and Kaplan's ownership share had been reduced to less than $11 \%$.

The fifth and final round of equity financing valued GO Corporation at over $\$ 100$ million $^{116}$ and allowed the company to raise another $\$ 13$ million. ${ }^{117}$ The result was another 4 million shares to the outside investors, who now owned over $75 \%$ of the shares of the company. Jerry Kaplan's ownership interest dipped to $9.4 \%$.

As illustrated by the effect of staged financing on Jerry Kaplan's ownership interest in GO Corporation, the key factor determining the dilutive effect of additional rounds of financing on the Entrepreneur is valuation. At each stage, the Entrepreneur and the Venture Capitalist together target an aggregate sum that must be raised to allow the company to progress to the next stage in its business plan. Valuation and the number of shares sold, therefore, are inversely proportional, and the fewer the number of shares sold, the higher the Entrepreneur's ownership interest. As a result, the Entrepreneur has a strong incentive to achieve a high valuation.

\section{Staged Financing and Venture Capitalist Reputation}

Unlike the Entrepreneur, the Venture Capitalist is not susceptible to dilution because the Venture Capitalist has a fixed claim, enforced by the right of first refusal in all additional financings. Nevertheless, the Venture Capitalist has incentives to maximize valuation at each stage of the financing process. Those incentives derive primarily from the reputational effects of high valuations. The Venture Capitalist's reputation is important in many contexts, including fundraising, investing, adding value, and exiting. In the fundraising context, current and potential investors in the Venture Capitalist's funds are the target group; in the investing context, Entrepreneurs are the target group; in

107. Id. at $62-63$.

108. Id. at 70 .

109. Id. at 79 (also noting the per share price of $\$ 0.75$ ).

110. KAPLAN, supra note 8 , at 80 .

111. Because of the uncertainty regarding the exact amount of the investment, these percentages were calculated based on an investment of $\$ 6$ million.

112. GO Corporation had also received some debt financing, including a loan from IBM. See KAPLAN, supra note 8 , at 145 .

113. Id. at 151 .

114. Id. at 153 .

115. The number of shares was calculated using a per share price of $\$ 2.50$. See id. at 151 .

116. Id. at 220 .

117. KAPLAN, supra note 8, at 223 (noting that the company received $\$ 12,935,503.70$, after deducting "a little over" $\$ 250$ in interest). 
the context of adding value, managers, suppliers, distributors, customers, and others in the Venture Capitalist's industry specialization, as well as other investors in the Venture Capitalist's portfolio companies, are the target groups; and in the exiting context, the public capital markets (including underwriters) are the target group. Venture Capitalist reputation in each of these contexts is important in providing incentives for the Venture Capitalist to maximize the value of a portfolio company at each stage of financing.

\section{Fundraising}

Venture capitalists raise money frequently. ${ }^{118}$ To attract investors to their funds, venture capitalists strive to develop a reputation for producing successful companies. In fact, as Paul Gompers has explained, the desire among young venture capitalists to produce a track record of success may lead to "grandstanding," the practice of forcing a company to go public early, in hope of enhancing the venture capitalist's reputation. ${ }^{119}$ Gompers and Joshua Lerner have also shown that, following the initial public offering of a portfolio company, venture capitalists often act on inside information to distribute shares of the portfolio companies after significant increases in the market prices of the shares. ${ }^{120}$ This strategy has several advantages for the Venture Capitalist over selling the shares and distributing the proceeds, including the maximization of the stated return of the Venture Capitalist's fund. ${ }^{121}$ Both grandstanding and this legal form of insider trading evidence the pressures felt by the Venture Capitalist to improve the return on investments. Those same pressures also inspire the Venture Capitalist to exert effort in maximizing the valuation of portfolio companies at each investment stage, thus ensuring that returns reported to fund investors are high.

\section{Investing}

Entrepreneurs care very much about who they hire as venture capitalists. For example, Kaplan described Doerr as "legendary" and noted that he had invested in many other successful companies. ${ }^{122}$ Entrepreneurs in the survey discussed above ${ }^{123}$ concluded that a venture capitalist's reputation for investing in successful companies was the most important consideration in selecting a Venture Capitalist-more important than any value-added service and more important than valuation. ${ }^{124}$ The Venture Capitalist's reputation for investing in successful companies may depend in part on the Venture

118. Paul Gompers \& Josh Lerner, Venture Capital Distributions: Short-Run and Long-Run Reactions, 53 J. FIN. 2161, 2164 (1998) (noting that "Venture capital funds have contractually determined lifetimes of about one decade, but the typical venture organization raises a new fund every few years").

119. Paul A. Gompers, Grandstanding in the Venture Capital Industry, 42 J. FIN. ECON. 133 (1996). Sharon Gifford has offered an alternative explanation for this phenomenon, suggesting that "Younger VC firms have fewer opportunities to invest in high-quality ventures, and so have a lower opportunity cost of time and money, [thus leading] young firms to monitor their portfolio firms more frequently and more times, which may allow them to go public sooner." Gifford, supra note 2, at 473.

120. Gompers \& Lemer, supra note 118 , at 2166.

121. Id. ("A venture capitalist's reputational concerns may not overcome the incentive to distribute overvalued shares.").

122. KAPLAN, supra note 8, at 23.

123. See supra note 24 and accompanying text.

124. Smith, supra note 24 . 
Capitalist's ability to achieve high valuations in the staged financings. As noted above, the higher the valuation, the larger the ownership interest retained by the Entrepreneur-a fact that may affect the reputation of the Venture Capitalist among future entrepreneurs. ${ }^{125}$ Even if the market for venture capitalist reputation among entrepreneurs is not completely efficient, one suspects that venture capitalists are motivated to maximize valuations at each investment stage in part by their desire to enhance their reputation among entrepreneurs.

\section{Adding Value}

Venture capital is expensive. The value-added services provided by the Venture Capitalist comprise a large part of the consideration flowing to the Entrepreneur. Bernard Black and Ronald Gilson recently described the importance of reputation in the context of adding value to portfolio companies:

Talented managers are more likely to invest their human capital in a company financed by a respected venture capital fund, because the venture capitalist's participation provides a credible signal about the company's likelihood of success. Suppliers will be more willing to risk committing capacity and extending trade credit to a company with respected venture capital backers. Customers will take more seriously the company's promise of future product delivery if a venture capitalist both vouches for and monitors its management and technical progress. ${ }^{126}$

As noted above, the Venture Capitalist also adds value by assisting the Entrepreneur in obtaining additional financing. ${ }^{127}$ Reputation is critical in developing a network of potential co-investors who will interpret the Venture Capitalist's involvement as a signal of the quality of the Entrepreneur. ${ }^{128}$ Reputation in this context may be enhanced by achieving higher valuations in each stage of a venture's growth. The higher the valuation, the higher the return on investment the Venture Capitalist is able to report to potential investors. ${ }^{129}$ Thus, the incentives of the Venture Capitalist and the Entrepreneur appear to be aligned with respect to valuation in staged financing.

125. See id. (survey showing reputation for "allowing entrepreneurs to retain large ownership share[s]" was of some importance to entrepreneurs). For anecdotal evidence of the importance of this reputational factor, see Anthony B. Perkins, You Too Can Be A Winner!, 32 Red HERRING ONLINE (June 1996) <http://www.herring. com/mag/issue32/angler.html>:

When you talk to Jim Clark it is clear that he still harbors some resentment for giving up $40 \%$ of his stock in Silicon Graphics to The Mayfield Fund and the other first-round VCs for only $\$ 800,000$. "By the time SGI went through a couple of public offerings, I ended up with only $1 \%$ Id. of the company. In retrospect, that kind of hurts," Mr. Clark told The Herring last fall.

126. Black \& Gilson, supra note 45 , at 254.

127. See supra Part II.B.2.

128. In the context of raising additional financing, the Venture Capitalist has an incentive to play the honest broker between the Entrepreneur and other investors. See Admati \& Pfleiderer, supra note 53, at 387 ("If any reputational assets are at stake either with outside investors or with the entrepreneur, the venture capitalist will clearly reveal the information truthfully, thereby resolving the information asymmetry.").

129. Id. Even though the Venture Capitalist has an incentive to obtain a high valuation, there is no incentive to overprice (or underprice) in subsequent rounds of financing. As noted by Admati and Pfleiderer: 


\section{Exiting}

Ample empirical work links the reputation of the Venture Capitalist to success in the market for initial public offerings. ${ }^{130}$ Venture-backed companies tend to be younger and less developed than other companies that consummate initial public offerings. ${ }^{131}$ Since initial public offerings are the exit option that produce the greatest returns, the Venture Capitalist has a particularly strong incentive to prepare a company for that event (perhaps too great an incentive, as evidenced by the grandstanding phenomenon discussed above). ${ }^{132}$ Maximizing the valuation of a portfolio company at each investment stage is a side effect of this process. The sooner the Venture Capitalist creates value, the sooner the Venture Capitalist is able to exit and secure the return on investment that is the goal of this process. An initial public offering is not the only means of exit. Many venturebacked companies are acquired by larger companies. In this circumstance, the last round of venture financing may be a key point of reference in discussions regarding valuation.

\section{The Role of the Lead Investor}

The importance of valuation in staged financing shines the spotlight on the lead investor of each new investment stage. Kaplan describes the role of the lead investor as follows:

First the current investors have to commit themselves to participating in the new round. This shows that they remain convinced of the merits of the venture. However, they cannot credibly set the price, because they are usually interested in "writing up" the value of their portfolio to improve the rate of return they can report to their own investors. Therefore the price must be established by a new investor, called the lead. The lead is responsible for negotiating terms with the company. Then, in order to spread the risk-and give the lead investors confidence that they aren't going to look like fools if the company goes bust-

\footnotetext{
An important feature of the fixed-fraction contract is that although the venture capitalist purchases new securities in later financing rounds, his payoff is independent of the pricing of any newly issued securities. The pricing of new securities only affects the division of surplus between the entrepreneur and outside investors, where the entrepreneur gains if new securities are overpriced and outsiders gain if they are underpriced relative to their value given all available information. Intuitively, the venture capitalist's incentives as a "new shareholder" to underprice new securities (and thereby take value away from the entrepreneur) are exactly offset by his incentives as an "old shareholder" to overprice them (and thereby take away value from outside investors). Since he cannot gain by mispricing the new securities, the venture capitalist can be given the responsibility of pricing those securities and revealing the information he knows.
}

Id. at 373-74.

130. See Christopher B. Barry et al., The Role of Venture Capital in the Creation of Public Companies: Evidence From the Going Public Process, 27 J. FIN. ECON. 447 (1990); William L. Megginson \& Kathleen A. Weiss, Venture Capitalist Certification in Initial Public Offerings, 46 J. FIN. 879 (1991).

131. See Timothy H. Lin \& Richard L. Smith, Insider Reputation and Selling Decisions: The Unwinding of Venture Capital Investments during Equity IPOs, 4 J. CORP. FIN. 241, 252-54 (1998)

132. See supra Part V.C.1. 
the deal is syndicated to the other interested parties that the company has been courting. 133

By setting the valuation, the lead investor acts in a manner similar to the principal described in the economic models discussed in Part IV above. She breaks the budget, not by appropriating all of the output for herself as envisioned by Holmstrom's model, but by allocating a share of the output to herself through discounted valuation.

The lead investor seems to act like the principal in Holmstrom's model in the sense that she has the power to realign the claims of the Entrepreneur. Regarding GO Corporation, for example, the lead investors reduced Jerry Kaplan's ownership claim against the corporation with each investment. ${ }^{134}$ The level of reduction was dependent on the valuation assigned to the company. Presumably, an Entrepreneur who had not proven himself worthy of additional investment could have his ownership claim reduced to zero (Holmstrom's draconian solution), either through termination by the Venture Capitalist or by the refusal of investors to invest.

The lead investor also attacks the team production problem by enforcing a bonding arrangement entered into by the Entrepreneur and the Venture Capitalist at the inception of the venture. By working on behalf of a new venture and accepting a lower salary than would be available from a more mature company, the Entrepreneur bonds his performance. Similarly, the Venture Capitalist bonds his performance by investing capital with no fixed return and by investing value-added services without direct compensation. Like the principal in McAfee and McMillan's model, the lead investor of each new round of financing receives the value of those inputs and in turn distributes the output of the venture to both parties in the form of higher valuations for their shares. Whether realigning ownership claims or enforcing bonding arrangements, the lead investor plays a crucial role in providing the incentives necessary to resolve the team production problem.

\section{CONCLUSION}

The real world is a messy place, and venture capital financings produce a complicated relationship between the Entrepreneur and the Venture Capitalist. Even relatively simple models of team production are difficult to transport into real contracts, which are costly to draft and enforce. In this light one should be humble about the prospects for fully resolving the team production problem in venture capital contracting.

Moreover, much is still unknown about the venture capital relationship and about the contracts used to structure it. For example, how do venture capitalists really decide whether to abandon a venture? How efficient is the market for venture capitalist reputation? Further questions surround the assumption that entrepreneurs and venture capitalists rationally deal with contracting problems. Although much progress has been made in investigating the psychological attributes of entrepreneurs, ${ }^{135}$ much remains to

133. KAPLAN, supra note 8, at 59-60.

134. See supra Part V.B.

135. Voluminous literature examining the psychological attributes of entrepreneurs has emerged. See, e.g., Robert A. Baron, Cognitive Mechanisms in Entrepreneurship: Why and When Entrepreneurs Think Differently Than Other People, 13 J. Bus. VENTURING 275 (1998); Roger Hudson \& Angeline W. McArthur, Contracting Strategies in Entrepreneurial and Established Firms, 18 ENTREPRENEURSHIP THEORY \& PRAC. 43 (1994); 
be done. And little is known about the biases of venture capitalists. It is quite possible that either or both routinely enter into contracts without addressing the team production problem.

Despite these difficulties in resolving the team production problem, staged financing appears to produce strong incentives countering the incentive to shirk. The traditional view of staged financing as a monitoring device is important but incomplete because it fails to accord full credit to the power of staged financing to provide incentives to both the Entrepreneur and the Venture Capitalist. Under principal-agent analysis, the possibility of abandonment by the Venture Capitalist is the key virtue of staged financing. The threat of abandonment inspires the Entrepreneur to exert enough effort to avoid abandonment. If the company nevertheless falls short of the performance standards required by the Venture Capitalist, actual abandonment cures the Venture Capitalist's adverse selection problem.

By viewing each financing decision as a toggle switch-merely a "stop/go" decision-under the control of the Venture Capitalist, ${ }^{136}$ the traditional view allows the Entrepreneur substantial room for undetectable shirking. A team production view of venture capital contracting reveals another virtue of staged financing, namely, the effect of recapitalizing the company based on the evaluation of a disinterested party. This view contributes three additional insights to the literature on staged financing: (1) it demonstrates the importance of the lead investor of each stage to act as a disinterested "principal" in evaluating the output of the Venture Capital Team; (2) it reveals the more compelling incentives facing the Entrepreneur; and (3) it shows that staged financing also provides incentives to the Venture Capitalist.

Leslie E. Palich \& D. Ray Bagby, Using Cognitive Theory to Explain Entrepreneurial Risk-Taking: Challenging Conventional Wisdom, 10 J. BuS. VENTURING 425 (1995).

136. See Gompers, supra note 1, at 1463 ("Venture capitalists monitor a firm's progress and discontinue funding the project if they learn negative information about future prospects."). 